УДК 341

DOI https://doi.org/10.51989/NUL.2021.5.9

\title{
ФОРМИ МИТНОГО ПРАВА ЄВРОПЕЙСЬКОГО СОЮЗУ
}

\section{Перепьолкін Сергій Михайлович,}

доктор юридичних наук, доцент, завідувач кафедри міжнародного права

Університету митної справи та фінансів

у статті здійснено класифікацію форм зовнішнього вираження чинного митного права Європейського Союзу. Стверджується, що серед усіх наявних форм митного права Європейського Союзу первинне місце належить його установчим угодам, зокрема Договору про Європейський Союз та Договору про функціонування Європейського Союзу. Водночас у повсякденному правовому регулюванні митних відносин у межах митної території Європейського Союзу основне місце належить актам, що ухвалюються установами Європейського Союзу. 3 огляду на це приділено увагу положенням: чинного Митного кодексу Європейського Союзу, затвердженого Реґламентом № 952/2013 Європейського парламенту та Ради Європейського Союзу від 9 жовтня 2013 року про встановлення Митного кодексу Європейського Союзу; Спільного митного тарифу, застосування якого здійснюється відповідно до Реґламенту Ради Європейського Економічного Співтовариства № 2658/87 від 23 липня 1987 року щодо тарифної і статистичної номенклатури і спільного митного тарифу; Реґламенту Ради Європейського Союзу № 1186/2009 від 16 листопада 2009 року, що встановлює систему Співтовариства для звільнення від сплати мит. Міжнародні угоди європейського Союзу, що містять положення в галузі митного права, класифіковано за такими видами: угоди між державами - членами Європейського Союзу; багатосторонні міжнародні угоди, учасником яких $\epsilon$ Європейський Союз та його держави-члени; угоди Європейського Союзу та його держав-членів із третіми державами або міжнародними організаціями. Проаналізовано статті Угоди про Асоціацію між Україною, з однієї сторони, та Європейським Союзом, Європейським співтовариством з атомної енергії і їхніми державами-членами, з іншої сторони, присвячені упорядкуванню відносин у сфері митного регулювання. Визначено роль національного митного права держав - членів Європейського Союзу та судової практики у формуванні, дії та розвитку митного права Європейського Союзу.

Ключові слова: митне право, Європейський Союз, форми права, реґламенти, міжнародні угоди, судова практика, стандарти.

\section{Perepolkin Serhii. Forms of customs law of the European Union}

In The article has been classified the forms of external expression of the current customs law of the European Union. It is considered that among all existing forms of customs law of the European Union, the primary place belongs to its founding agreements, in particular the Treaty on European Union and the Treaty on the Functioning of the European Union. At the same time, in the day-to-day legal regulation of customs relations within the customs territory of the European Union, the main place belongs to the legislative acts adopted by the institutions of the European Union. In view of the above, we have paid close attention to the provisions of: the current Customs Code of the European Union, approved by Regulation № 952/2013 of the European Parliament and the Council of the European Union of 9 October 2013 establishing the Customs Code of the European Union; The Common Customs Tariff, applied in accordance with the Regulation of the Council of the European Economic Community № 2658/87 of 23 July 1987 on the tariff and statistical nomenclature and on the Common Customs Tariff; Regulation (EC) № 1186/2009 of the Council of the European Union of 16 November 2009 establishing a Community system of reliefs from customs duty. International agreements of the European Union, containing provisions in the field of customs law, have been classified into the following types: agreements between member states of the European Union; multilateral international agreements to which the European Union and its Member States are parties; agreements of the European Union and its Member States with third countries or international organizations. We have analyzed the articles of the Association Agreement between Ukraine, on the one hand, and the EU, the European Atomic Energy Community and their Member States, on the other 
hand, on the regulation of relations in the field of customs regulation. Have been determined the role of the national customs law of the member states of the European Union and judicial practice in the formation, operation and development of the customs law of the European Union.

Key words: customs law, European Union, forms of law, regulations, international agreements, case law, standards.

Митне право $є$ однією з основних галузей права Європейського Союзу (далі $€ C)$. Сфера його дії поширюється не лише на $\in C$, держави-члени і фізичних та юридичних осіб або будь-які об'єднання осіб, які відповідно до законодавства ЄC або національного законодавства його державчленів визнаються такими, що мають право виконувати юридичні акти, а також і на інші держави. Зокрема, поступове наближення українського законодавства в митній сфері до митного законодавства ЄC, як це визначено у стандартах ЄС та міжнародних стандартах, зазначено у ст. 84 Угоди про Асоціацію між Україною, з однієї сторони, та ЄС, Європейським співтовариством 3 атомної енергії і їхніми державами-членами, з іншої сторони [18].

3 огляду на це різноманітні теоретичні та прикладні аспекти митного права ЄC досліджуються як представниками правової доктрини держав - членів ЄС (Г. Валантиєюс, Г.-М. Вольфґанґ, Т. Лайонс, М. Люкс, Т. Ові, А. Рогманн, К. Харден, М. Еркорека), так і третіх держав (Б.А. Кормич, Р. Криль, А.В. Мазур, М.Є. Романова, Ш.-Ц. Чен, В.В. Ченцов).

Аналіз останніх досліджень і публікацій у цій сфері засвідчив, що найчастіше вчені згадують у своїх працях лише окремі акти митного законодавства ЄC, наприклад Митний кодекс або Спільний митний тариф. Поширеною $€$ також практика розгляду актів митного законодавства $Є C$ на основі їх поділу на окремі групи. Наприклад, акти, що ухвалюються інституціями $\in C$, міжнародні угоди між державами членами $\in C$ або міжнародні угоди, договірною стороною яких $\in \in C$ тощо.

Водночас наукові дослідження присвячені комплексній характеристиці нині існуючих форм зовнішнього вираження правил поведінки митного права ЄС або прогнозуванню їх подальшого розвитку, украй рідко трапляються в науковій літературі. Тому мета статті полягає у здійсненні класифікації форм зовнішнього вираження чинного митного права $Є C$.
Досягнення встановленої мети сприятиме продовженню наукової дискусії щодо прогнозування подальшого розвитку змісту та форм митного права $\in C$, а також визначенню сучасного стану та перспектив впливу митного права $\in C$ на митне право України.

Отже, набуття повноправного членства України в ЄС вимагає від нашої держави узгодження вітчизняного митного права з митним правом ЄC. 3 огляду на це актуальним $\epsilon$ класифікувати форми зовнішнього вираження чинного митного права EC та загалом охарактеризувати його засади.

Серед усіх наявних форм митного права ЄС первинне місце належить його установчим угодам, зокрема Договору про Європейський Союз (далі - ДЄС) [9] та Договору про функціонування Європейського Союзу (далі - ДФЕС) [10]. У їхніх статтях закріплено численні важливі для митного права Союзу положення. Однак, якщо у статтях ДЄС загалом визначають цінності та принципи Союзу та безпосередньо не згадуються митний союз і складові частини митного права ЄC, то в тексті ДФЕС та його Протоколах регулюванню митних відносин приділяється значна увага. Наприклад, згідно зі ст. 3 ДФЄС, Союз має виключну компетенцію у сфері митного союзу. Зі свого боку, відповідно до ст. 31 ДФЕС, Мита Спільного митного тарифу встановлюються Радою на пропозицію Комісії. Важливі для здійснення правового регулювання митних відносин як між державами - членами $\in C$, так і із третіми країнами та територіями правила митного права закріплено також в таких статтях ДФЕС та Протоколах до нього: ст. ст. 28, 29 (Вільний рух товарів); ст. ст. 30, 32 (Митний союз); ст. 33 (Митне співробітництво); ст. ст. 34-37 (Заборона кількісних обмежень між державами-членами); ст. 349 (Загальні та прикінцеві положення); Протокол № 7 «Про привілеї та імунітети Європейського Союзу»; Протокол № 31 «Про імпорт до Європейського 
Союзу нафтопродуктів, перероблених на нідерландських Антильських островах»; Протокол № 34 «Про спеціальні положення щодо Гренландії» тощо.

Водночас у повсякденному правовому регулюванні митних відносин у межах митної території $\in C$ основне місце належить актам, що ухвалюються установами $\in C$. Серед таких актів центральне місце належить чинному Митному кодексу $\in C$ (далі - МК ЄC), затвердженому Реґламентом № 952/2013 Європейського парламенту та Ради ЄС від 9 жовтня 2013 р. про встановлення Митного кодексу Європейського Союзу [14].

За структурою МК ЄС складається із преамбули, 9 розділів, які вміщують 288 статей, та одного додатку - Кореляційної таблиці. У його змісті нормативно закріплені такі загальні правила та процедури, що застосовуються до товарів, увезених на митну територію ЄС або вивезених із неї: сфера застосування митного законодавства, завдання митниці та визначення; права й обов'язки осіб стосовно митного законодавства; конвертація валюти та часові обмеження; спільний митний тариф та тарифна класифікація товарів; походження товарів; виникнення митного боргу та гарантії для потенційного або наявного митного боргу; відшкодування та звільнення від сплати суми ввізного або вивізного мита; погашення митного боргу; загальні правила щодо митного статусу, поміщення товарів у митний режим, перевірка, випуск та розпорядження товарами; випуск у вільний обіг та звільнення від сплати ввізного мита; спеціальні процедури; товари, вивезені за митну територію $\in C$; електронні системи, спрощення, передача повноважень, процедура комітету та прикінцеві положення.

МК $\in C \in$ основним але не єдиним актом митного законодавства ЄC. Тому важливу роль для ефективного правового регулювання митних відносин у ЄС відіграють також інші реґламенти, ухвалені з метою сприяння виконанню положень МК $\in C:$ Делегований реґламент Комісії ЄC № 2015/2446 від 28 липня 2015 р.; Імплементаційний реґламент Комісії ЄС № 2015/2447 від 24 листопада 2015 р.; Д Делегований реґламент Комісії ЄC № 2016/341 від 17 грудня 2015 р. тощо.
Вкрай важливою складовою частиною митного права ЄС виступає Спільний митний тариф, застосування якого здійснюється відповідно до Реґламенту Ради ЄЕС № 2658/87 від 23 липня 1987 р. щодо тарифної і статистичної номенклатури і спільного митного тарифу [12].

Основу Спільного митного тарифу становить combined nomenclatur (далі - CN) систематизований перелік описів товарів, складений на основі Гармонізованої системи. Окрім цього, CN також використовують для статистики зовнішньої торгівлі співтовариства. На основі CN Комісія ЄC складає Інтегрований тариф ЄC TARIC (від французького терміна Tarif intégré des Communautés européennes). Юридично TARIC не $\epsilon$ частино митного законодавства $\in C$. Однак на практиці він активно використовується Комісією та компетентними органами держав-членів для реалізації заходів Союзу щодо імпорту, а також необхідною мірою експорту та торгівлі між державами-членами.

Основними цілями використання CN та TARIC $€$ : стягнення мит; позначення товарів, які підлягають обкладенню акцизами; позначення товарів, які обкладаються ПДВ за зниженими ставками; застосування імпортних та експортних нетарифних обмежень; ведення зовнішньоторговельної статистки. TARIC публікується щороку в Офіційному журналі $\in C$, а також $\epsilon$ доступним в електронному вигляді [17, с. 203].

Важливу частину митного права Союзу утворюють правила, що встановлюють систему звільнень від сплати мита. Як і у випадку зі Спільним митним тарифом $\in C$, через свої розміри система звільнення від сплати мита, яка діє в Союзі, викладена окремо від Митного кодексу, а саме в Реґламенті Ради (ЄС) № 1186/2009 від 16 листопада 2009 р., що встановлює систему Співтовариства для звільнення від сплати мит [11].

Ще однією формою митного права $\in C$ $\epsilon$ міжнародні угоди, що містять положення в галузі митного права в тому обсязі, у якому вони застосовуються в Союзі. Залежно від суб'єктного складу такі угоди можуть бути класифіковані за такими видами: угоди між державами членами ЄC (Конвенція про спрощення 
формальностей у торгівлі товарами від 20 травня 1987 р., Конвенція про процедуру загального транзиту від 20 травня 1987 р., Конвенція про взаємну допомогу та співробітництво між митними адміністраціями від 18 грудня 1997 р.); багатосторонні міжнародні угоди, учасником яких $\in \in C$ та його держави-члени (Міжнародна конвенція про спрощення та гармонізацію митних процедур від 18 травня 1973 р., Митна конвенція про міжнародні перевезення вантажів із застосування книжки МДП від 14 листопада 1975 р., Міжнародна конвенція про гармонізовану систему опису та кодування товарів від 14 червня 1983 р., Міжнародна конвенція про тимчасове ввезення від 26 червня 1990 р.); угоди ЄС та його держав-членів із третіми державами або міжнародними організаціями (Угода про асоціацію між Україною, з однієї сторони, та Європейським Союзом, Європейським співтовариством з атомної енергії і їхніми державами-членами, з іншої сторони, від 27 червня 2014 р. (далі - Угода про асоціацію). Так, в Угоді про асоціацію упорядкуванню взаємних відносин у сфері митного регулювання приділяється увага в таких статтях: ст. 27 «Визначення мита»; ст. 29 «Скасування ввізного мита»; ст. 31 «Експортне мито»; ст. 33 «36ори ті інші платежі»; ст. 49 «Правило щодо меншого мита»; ст. 50 «Застосування заходів та їх перегляд»; ст. 76 «Законодавство та процедури»; ст. 77 «Відносини з бізнес-спільнотою»; ст. 78 «3бори та платежі»; ст. 79 «Митна оцінка»; ст. 80 «Митне співробітництво»; ст. 81 «Взаємна адміністративна допомога в митних справах»; ст. 82 «Технічна допомога і розвиток потенціалу»; ст. 83 «Підкомітет 3 питань митного співробітництва»; ст. 84 «Наближення законодавства у митній сфері» тощо [1].

У сферах, не охоплених вищезазначеними актами митного законодавства $Є C$, або в яких законодавство Союзу передбачає чи дозволяє ухвалювати національні закони, застосовується законодавство тієї держави-члена, де товари розміщують у митний режим. Це стосується різних питань, зокрема: організаційної структури національних митних адміністрацій, порядку проходження служби в митних органах, класифікації митних правопорушень, видів і порядку застосування санкцій за вчинені митні правопорушення, процедури подання апеляцій на дії митних органів тощо. Варто врахувати, що сфера дії національного митного законодавства обмежена державними кордонами та не поширюється на всю митну територію ЄС.

Загалом держави - члени ЄС досягли значного прогресу в напрямі застосування митного законодавства $\in C$, ніж це робила єдина адміністрація. Проте для повної злагодженості дій у цій сфері їм потрібно ще багато працювати. На практиці постійно виникають випадки неоднозначного тлумачення та застосування митного законодавства ЄС різними правозастосовними органами держав - членів $\in C$. Найчастіше такі ситуації виникають із питань здійснення митного контролю за імпортом товарів, нарахування розміру митних зборів, встановлення походження товарів, визначення їхнього місця в комбіновані номенклатурі та накладення митних санкцій.

Тому вагомий вплив на формування, дію та розвиток митного права Союзу здійснює практика Суду $Є С$, який своїми рішеннями значною мірою конкретизував положення установчих договорів та зобов'язав окремі держави-члени скасувати ті або інші заходи обмеження торгівлі, які суперечили цим нормам. У цьому контексті найбільш відомою $€$ справа Van Gend en Loos v. Nederlandse Adminastratie der Belastingen, 1963 р., рішенням у якій було підтверджено принцип прямої дії норм Римського договору щодо скасування мит між державами-членами [3].

За результатом розгляду іншої справи Commission v. Italy, 1968 р. - Судом ЄС було визначено відсутнє в установчих договорах ЄC поняття «товар» [4].

Велике значення практиці Суду $\in C$ надається в діяльності національних судових органів. Так, на запити національних судів держав-членів Суд ЄС ухвалює рішення щодо інтерпретації Спільного митного тарифу, зокрема й реґламентів, ухвалених для його інтерпретації, що дає судам можливість вирішувати судові справи, які перебувають у них на розгляді. Окрім цього, національні суди проводять оцінку фактичних обставин справи 
на основі інтерпретаційних критеріїв, викладених Судом ЄС [2].

Найчастіше на розгляд Суду передаються справи в таких сферах митного регулювання, як: тарифна класифікація товарів [8]; митні процедури [5]; митна оцінка товарів [7]; визначення походження товарів [6].

Як ще одну форму митного права ЄC вітчизняні вчені розглядають різноманітні, розроблені установами й органами ЄC митні стандарти, зокрема "Customs blueprints" [13]. Однак єдиного узгодженого підходу із цього питання поки що не вироблено [15; 16; 19]. Тому подальше наукове вивчення форм митного права $Є C$ та перспектив його розвитку зберігають свою актуальність.

У підсумку можна дійти висновку, що для сучасного митного права $\in C$ характерні такі форми зовнішнього вираження: установчі угоди $Є C$; акти, що ухвалюються установами ЄC; міжнародні угоди, укладені як між державами - членами ЄC, так і із третіми державами; національне митне право держав - членів ЄC; практика застосування митного законодавства ЄC, зокрема судова практика.

\section{ЛITEPATУPA:}

1. Association Agreement between the European Union and its Member States, of the one part, and Ukraine, of the other part. Official Journal of the European Union. 2014. № L 161. P. 3-2137.

2. Case 167/84. Hauptzollamt Bremen - Freihafen v. J. Henr. Drünert Holzimport. URL: https://eur-lex.europa.eu/legal-content/EN/TXT/?uri=CELEX\%3A61984CJ0167 (дата звернення: 13.09.2021).

3. Case 26-62. NV Algemene Transport- en Expeditie Onderneming van Gend \& Loos v. Netherlands Inland Revenue Administration. URL: https://eur-lex.europa.eu/legal-content/EN/ TXT/?uri=CELEX\%3A61962CJ0026 (дата звернення: 13.09.2021).

4. Case 7-68. Commission of the European Communities v. Italian Republic. URL: https://eur-lex. europa.eu/legal-content/EN/TXT/?uri=CELEX\%3A61968CJ0007 (дата звернення: 13.09.2021).

5. Case C-156/16. Tigers GmbH v Hauptzollamt Landshut. URL : https://eur-lex.europa.eu/ legal-content/EN/TXT/?uri=CELEX\%3A62016CC0156 (дата звернення: 13.09.2021).

6. Case C-373/08. Hoesch Metals and Alloys GmbH v. Hauptzollamt Aachen. URL : https://eur-lex. europa.eu/legal-content/EN/TXT/?uri=CELEX\%3A62008CJ0373 (дата звернення: 13.09.2021).

7. Case C-46/16. Valsts ienēmumu dienests v 'LS Customs Services' SIA. Official Journal of the European Union. 2018. № C 5. P. 6-7.

8. Case C-58/14. Hauptzollamt Hannover v. Amazon EU Sàrl. URL : https://eur-lex.europa. eu/legal-content/EN/TXT/?uri=CELEX\%3A62014CJ0058 (дата звернення: 13.09.2021).

9. Consolidated version of the Treaty on European Union. Official Journal of the European Union. 2012. № C 326. P. 13-45.

10. Consolidated version of the Treaty on the Functioning of the European Union. Official Journal of the European Union. 2012. № C 326. P. 47-390.

11. Council Regulation (EC) № 1186/2009 of 16 November 2009 setting up a Community system of reliefs from customs duty (codified version). Official Journal of the European Union. 2009. № L 324. P. 23-57.

12. Council Regulation (EEC) № 2658/87 of 23 July 1987 on the tariff and statistical nomenclature and on the Common Customs Tariff. Official Journal of the European Communities. 1987. № L 256. P. 1-675.

13. Customs Blueprints - pathways to modern customs / Luxembourg : Publications Office of the European Union. 2015. 140 p.

14. Regulation (EU) № 952/2013 of the European Parliament and of the Council of 9 October 2013 laying down the Union Customs Code. Official Journal of the European Union. 2013. № L 269. P. $1-101$.

15. Дорофеєва Л.М. Нормативно-правове закріплення міжнародних стандартів митної справи. Науковий вісник Міжнародного гуманітарного університету. Серія «Юриспруденція». 2017. № 26. С. 16-19. 
16. Кормич Б.А. Про Customs Blueprints, або що не так з митною реформою. Obozrevatel.ua. 2017. URL: https://www.mdoffice.com.ua/ua/aSNewsDic.getNews?dat=27042017\&num_ c=593398 (дата звернення: 13.09.2021).

17. Право Європейського Союзу. Особлива частина : навчальний посібник / Т.О. Анцупова та ін. ; за ред. М.Р. Аракеляна, О.К. Вишнякова. Київ : Істина, 2010. 528 с.

18. Угода про Асоціацію між Україною, з однієї сторони, та Європейським Союзом, Європейським співтовариством з атомної енергії і їхніми державами-членами, з іншої сторони, від 27 червня 2014 р. Офіційний вісник України. 2014. № 75. Т. 1. Ст. 2125.

19. Ченцов В.В. Міжнародні стандарти модернізації митних адміністрацій. Державне управління та місцеве самоврядування. 2015. Вип. 4 (27). С. 219-229. 